\title{
Miranda
}

Revue pluridisciplinaire du monde anglophone /

Multidisciplinary peer-reviewed journal on the English-

speaking world

15 | 2017

Lolita at 60 / Staging American Bodies

\section{Spectacle Lynching and Textual Responses}

\section{Wendy Harding}

\section{OpenEdition}

\section{Journals}

Electronic version

URL: http://journals.openedition.org/miranda/10493

DOI: 10.4000/miranda.10493

ISSN: 2108-6559

\section{Publisher}

Université Toulouse - Jean Jaurès

Electronic reference

Wendy Harding, "Spectacle Lynching and Textual Responses", Miranda [Online], 15 | 2017, Online since 18 September 2017, connection on 16 February 2021. URL: http://journals.openedition.org/miranda/ 10493 ; DOI: https://doi.org/10.4000/miranda.10493

This text was automatically generated on 16 February 2021.

\section{$\Theta \Theta \Theta \Theta$}

Miranda is licensed under a Creative Commons Attribution-NonCommercial-NoDerivatives 4.0 International License. 


\title{
Spectacle Lynching and Textual Responses
}

\author{
Wendy Harding
}

Among the many horrific accounts of the lynching of African Americans, ${ }^{1}$ there is one that stands out as being paradoxically both anomalous and paradigmatic. On April 20, 1911, Will Potter was arrested in Livermore, Kentucky for shooting a white man. ${ }^{2}$ According to The New York Times report he was taken to the local opera house and "his body was riddled with bullets from the guns of an audience of half a hundred determined avengers" (April 21, 1911; quoted and discussed in Dray 177-8). The Kentucky newspapers reported that there was an admission charge to attend the lynching: "Those who purchased orchestra seats were allowed to empty their guns into the hanging figure, while those in the gallery only had one shot" (Smith, McDaniel and Hardin 332). The New York Times report plays up the theatrical dimension, calling the lynching "a melodrama" staged against a backdrop of "woodland scenery arranged for the presentation of a much milder drama." The Livermore lynching is unusual because it is the only one I have come across that took place inside a theatre, but it also reproduces a pattern. First, it gathers the community in a ritual that affirms racial divisions, and second, it stages scenes of extreme violence. Indeed the violence of racially motivated lynching goes hand in hand with the aim to make a spectacle out of the victim and to make that spectacle available for public consumption. ${ }^{3}$ Exhibition, whether through the staging of the event or in the diffusion of texts and images recording it, is integral to the lynching ritual. Moreover, the persistence of textual and visual representations of the ritual means that the terror they inspire does not lessen over time. ${ }^{4}$ Images of mutilated black corpses hanging from Southern trees have continued to haunt the nation's collective memory, and they have evoked multiple forms of response in the works of African American artists and writers. Lynching imagery burns itself into one's consciousness, demanding explanations and eliciting counter-representations. I will first consider how the ritual of lynching helped produce the racial distinctions defining the communities that practiced it. To that end, my discussion of representations of the Livermore incident will be followed by an analysis of some of the photographs reproduced in James Allen's Without Sanctuary: Lynching 
Photography in America. ${ }^{5}$ Then I will discuss how the diffusion of photographs and reports representing lynchings enforced racial divisions on a wider territorial scale. Finally, I will examine some of the ways in which African American writers have responded to the violence of those representations.

\section{The Lynching spectacle and the performance of race}

2 The spectacle of lynching-the event itself-was staged by and for the white communities, and participating in it was a way to confirm the racial categories structuring American society through their enactment. ${ }^{6}$ The performative dimension of the ritual is acknowledged in newspaper reports that resort to theatrical metaphors. Not surprisingly, this is particularly evident in accounts of the lynching at the Livermore opera house. In a follow-up to its initial report, The New York Times ironized about the distribution of roles at the event: "In the residents of Livermore, the dramatic sense is strongly developed, and it is quite certain that the Negro who made in the Livermore opera house his first and last appearance on any stage will never again offend the delicate and tender sensibilities of his fellow townsmen" (April 22, 1911; Dray 178). The glib tone of the reports illustrates the low value assigned to black lives, even as it ironizes about the qualities attributed to the two races in the construction of racial difference. The white spectators assert their racial prerogative by lynching the black offender. The newspaper report does not need to designate the spectators' race; merely by noting that the victim was "Negro," it defines the audience as white. Will Potter was one among thousands of other African Americans put to death in cruel and unusual ways in the decades spanning the end of the $19^{\text {th }}$ century and the beginning of the $20^{\text {th }}$ century. ${ }^{7}$

3 Through repetition, albeit with variation, the torture and murder of suspected wrongdoers acquired a ritual structure and sense. Like religious rituals, lynching served to bond the white community and to assert its power. ${ }^{8}$ African Americans were assigned the role of scapegoats in the drama of lynching. The typical accusation involved their imputed lust for white women. In fact, any form of encroachment on the white community's prerogatives, from economic success to a nonsubmissive attitude, could set the process in motion. ${ }^{9}$ But, in contrast to the rituals Girard discusses, ${ }^{10}$ the sacrifice of the black pharmakos does not bring about the healing of social fractures. Instead, the ritual confirms the divided social order of post-Civil War American society by fashioning the victim into an icon of the abjection that signifies the binary opposite of whiteness. Thus, in participating in the lynching ritual, people affirm their membership in the dominant race. ${ }^{11}$ In response to shifting social and economic dynamics like the rise of consumer culture (Hale) or the fluctuations in the cotton market (Tolnay and Beck) the white community renewed and reiterated this most brutal performative act. Rites of terror consolidated the social divisions encoded in the Jim Crow laws.

4 As part of the lynching ritual, white participants would inscribe on the victims' bodies the signs of their subordination to white rule so that their mutilated corpses came to emblematize racial difference. As Foucault insists: "torture forms part of a ritual. It is an element in the liturgy of punishment; ... it is intended, either by the scar it leaves on the body, or by the spectacle that accompanies it, to brand the victim with infamy" (Foucault 34). When the lynching party had done its work, the victim's body would 
often be displayed in a public place as a message to the community at large. This practice deliberately violates cultural customs that aim at honoring the dead, thereby showing the white supremacists' disdain for the black victims, their families and their community.

This public torture was visually documented, and the photographs of the mutilated victims were circulated in the community. Ample evidence of this phenomenon is found in Without Sanctuary: Lynching Photography in America, the book that gathers James Allen's collection of lynching memorabilia. The lynching ritual focuses on the body, asserting white power by attempting to reduce the transgressor to a thing deprived of humanity. To this end, black bodies were cut up like meat both before and after death, with less respect or compassion than people show for animals. One of the artefacts in Allen's collection is a set of three postcards showing the lynching of Frank Embree (July 22, 1899, Fayette Missouri). The set was bound together with purple thread. The triptych shows the lacerated victim from front and back and then displays his corpse hanging from a tree (Allen et al., Figures 42-44). The naked man stands in the foreground above the clothed observers, mounted on a wagon with hands chained together (Appendix, Figure 1) ${ }^{12}$ His body contrasts with those of the observers, all of whom are dressed in hats and jackets or waistcoats that proclaim their status as respectable citizens. The print heightens the contrast between the victim's dark skin and hair and the crowd's white shirts that merge with the pale sky in the background.

Burning the body reduced it to an even more grotesque deviation from the human form. One particularly horrifying postcard shows a charred corpse hung from a utility pole in the center of Robinson, Texas (Appendix Figure 2). ${ }^{13}$ Another way to abase the African American body was to make it into a figure of fun. In the photograph on the half title page that opens the Without Sanctuary collection, ${ }^{14}$ a man's corpse has been seated in a chair and his face grotesquely painted so that it looks like a clown's. A hand holding a stick like a puppeteer props up the head (Appendix Figure 3). In another photograph, the spectators have placed a hat on the victim's head. With his neck broken by the rope, the man looks like a comically pathetic marionette hanging from a string (Appendix Figure 4; cf. Allen et al. Figure 93). Besides illustrating black degradation, these photographs also convey the disturbing holiday atmosphere of the lynching ritual. The victims' bodies are displayed like exhibits at circuses or freak shows, and the white community gathers round them in a celebratory mood, having suspended work and school for the occasion.

7 Officially, by the end of the $19^{\text {th }}$ century, American justice had moved toward the modern forms of punishment that Foucault describes in Discipline and Punishincarceration and private executions. The lynching ritual corresponds to the older modes of public torture and execution in which the immensity of the crime justified the immeasurable suffering of the offender. The extreme cruelty of the punishments exacted on the bodies of those who transgressed racial boundaries recalls those that the regicide Damiens suffered (Foucault 3-5). Offences against the white community apparently constituted a form of lèse-majesté that was felt to require an extreme response.

8 Usually, vigilante justice operates where official structures are lacking, but this was not the case in the states where most of the racially motivated lynchings took place. In those states, African Americans accused of crimes could have expected speedy convictions by all-white juries. Why then did the community ignore legal procedures 
and revert to practices that resembled the archaic modes of torture, mutilation, and execution? Clearly, the lynching ritual showed the community that despite the passage of the Fourteenth Amendment to the Constitution, African Americans were excluded from the rights and privileges accorded to American citizens. The lynchings that took place right outside the courthouse and in front of the town's eminent citizens give ample proof of their disenfranchisement. A photograph found in Texas gives a visual record of one such lynching; it shows a man hanging from a tree in front of a courthouse whose architecture "suggests a Texas origin" according to the notes in Without Sanctuary (Appendix Figure 5). ${ }^{15}$

\section{The violence of representation}

While the actual performances of the lynching ritual are obviously not recoverable for analysis, their traces persist in the many images and writings produced in response to them. In fact capturing a visual record was an integral part of the lynching ritual's violence. Pictorial or textual images of lynched black bodies restage the original murders, so that looking at the souvenir pictures or postcards and reading the accounts is the equivalent of attendance by procuration. Indeed, Horst Bredekamp insists that: "A form of feedback has probably always existed between acts of violence like lynchings and their photographic diffusion, to the extent that photographs were considered as part of the execution and the fact of looking at them as equivalent to participating in that execution" (Bredekamp 212). ${ }^{16}$ Photographs extended the spectacle far beyond its immediate moment, thereby enlarging the community of both participants and victims.

10 Through representation, the lynching ritual helped fashion the mythology of race. Those members of the public who saw themselves as white would find their claim to superiority confirmed in the representations of lynching. Those identified as black would see the reverse. The texts and images describing the rituals of terror ensure that their effect spreads over time and space. The testimonies to events renew them for the present, reinforcing their message of racial difference. Thus, they continue to inflict personal injury on African Americans, all the more so as racial divisions in America continue to be enforced through acts of violence. Responding at the start of the $21^{\text {st }}$ century to the photographs collected in Without Sanctuary, Hinton Als writes: "I looked at these pictures, and what I saw in them, in addition to the obvious, was the way in which I'm regarded, by any number of people: as a nigger. And it is as one that I felt my neck snap and my heart break, while looking at these pictures" (Allen et al. 39). Als feels that the photographs address him personally, and his response is physical, felt in both heart and neck. Lynching is the ultimate form of racial marking; it defines its immediate victims as subalterns, even sub-humans, and that stigma extends to those who in any way resemble them. Thus Als continues: "I don't know many people who wouldn't feel like a nigger looking at these pictures, all fucked up and hurt, killed by eyes and hands that can't stand yours" (Allen et al. 40). His comment on Allen's collection suggests that the violence of racism resides in the eyes that see those with darker skin as abject and yet do not look away, as well as in the hands that act on that stigmatization either by taking part in the lynching, by taking the pictures, or by circulating them afterwards. 
11 Photographs, as Barthes so memorably insists, differ from other images in that their viewers "can never deny that the thing has been there" (Barthes 1981, 76; Barthes' italics). And in a remark that seems particularly relevant to lynching photography, he writes: "In every photograph there is the always stupefying evidence of this is how it was, giving us, by a precious miracle, a reality from which we are sheltered" (Barthes 1977, 44). Some of the lynching images reveal that it was precisely the indexical nature of photography-its indisputable connection to the real-that encouraged the lynchers to pose with their victims. The photograph discussed above (Appendix Figure 4), in which one man points to the hanging body with his cane, draws the viewer's eye not only to the lynch victim, but also, in a form of mise en abyme, to the witness's own presence. In another photograph in which the white observers pose in front of the bodies of Thomas Shipp and Abram Smith (Allen et al., Figure 31), a man points to the bodies hanging above him with his finger, while looking directly at the camera (Appendix Figure 6; detail, Appendix Figure 7). These photographs, especially the latter, are reminiscent of Christian iconography where the pointing figure bears witness. In the Grunewald crucifixion (Appendix Figure 8), as in many other representations of the Passion of Christ, John the Baptist stands at the left of the cross, pointing with his right index finger, while in his left hand, he holds a book to show that Christ's killing fulfills the old Testament prophesies. The anachronistic prophet figure thus illustrates that the death has a purpose in the scheme of salvation. In contrast, the lynching photographs show that the victims are unequivocally annihilated. The only thing their deaths redeem is their purported infringement of white supremacy.

Images of the event travesty the most common purpose of privately owned photographs, which usually feature family members and seek to suspend time, keeping loved ones alive in memory even after they die. ${ }^{17}$ In the lynching photographs, the victim's inert bodies contrast with those of the white spectators whose attitudes and expressions testify to their continuing vitality, to the triumph of life. In particular, the smiling couple in the left hand corner of the photograph of the lynching of shipp and Smith seem happily engaged in the ordinary rituals of courting, while, under magnification, the photograph reveals, troublingly, that the girls clutch "ragged swatches of dark cloth," souvenirs from the victims' clothing (Allen et al., 176).

For the whites, a spectacle lynching was an important community event that local newspapers announced in advance. The spectators posed before the camera with their victims as if commemorating a festive celebration, and their photographs ensured that the lynching scene would have an afterlife. Some of the postcards in James Allen's collection contain handwritten messages commenting on the photographic image. The postcard showing the charred corpse of Jesse Washington bears the following message from a young man to his parents: "This is the barbecue we had last night. My picture is to the left with a cross over it your son Joe" (Allen et al., Figure 26). This use of the term for an outdoor picnic to describe the burning of a human being is not uncommon; Allen finds "repeated references to eating found in lynching related correspondence, such as 'coon cooking,' 'barbecue,' and 'main fare"' (174-175). This discourse hints at the lynchers' awareness that their ritual violates the rules of human decency. The irony that intimates violations of the taboo against cannibalism mediates the discomfort that their acts might have occasioned. At the same time, the culinary terms acknowledge the eminently social function of the ritual. For a young white man, attending a lynching was a rite of passage, a sign of his membership in his community. ${ }^{18}$ 

friends and relatives, or published in newspapers, pamphlets or books, photographs of lynchings circulated through the nation's territory and, in the process, accumulated textual commentary that either justified or condemned the events that produced them. Evidence of the national debate about lynching is gathered in a book published by P. L. James in 1893, the year of the events that it chronicles. It bears the very explicit title The Facts in the Case of the Horrible Murder of Little Myrtle Vance and its fearful Expiation at Paris, Texas, February $1^{\text {st }}, 1893$, with Photographic Illustrations. The book is unusual in the methodical way in which it structures the account of the lynching as a Texan morality play. ${ }^{19}$ It provides a double account of events: first, a dramatic narrative illustrated by photographs adopts the running metaphor of a morality play in which the sinner meets a fiery end; then, a collection of archival material such as newspaper reports, letters, and telegrams documents contemporary public opinion either for or against the lynching.

The narrative describing the lynching begins with a portrait of the villain. His depiction echoes the stereotyped racial profiles developed by $19^{\text {th }}$-century physiognomists, who claimed that the brains of black males were considerably smaller than those of other races and that this demonstrated their inferiority (Wiegman 53-55):

A brawny muscular body, surmounted by a small head, developed wholly in the direction of the animal passions and appetites; devoid of any humanizing sensibilities, or sympathies, a quiet, industrious servant when sober, a fiend incarnate, when in liquor, such, briefly stated, is a view of the general character of Henry Smith, whose name and fame have been sounded down every avenue of the civilized world since February 1, 1893. (James 3)

Implicitly, a man of this racial type is tolerated as long as he knows his place as "a quiet, industrious servant," but when he abandons that role, he becomes "a fiend incarnate." The narrative relates how the rape and murder took place at "the scene of ... devilish debauchery" chosen by the villain. A photograph of the murder scene with the caption "THE FINDING OF THE CHILD'S DEAD BODY" accompanies the text. The photograph suggests that in order to supplement the images taken at the lynching, the participants actually reenacted some of the scenes.

17 As in the medieval morality plays, the whole community participates in a drama that unfolds in such an orderly and pre-scripted manner that the author can divide it into four acts. In Act I little Mabel Vance is found to be missing: "The curtain rises on the afternoon of January $26^{\text {th }}, 1893$, and the play begins" (James 5). In Act II, the child's body is discovered and "the people of Paris laid the desecrated body away to rest and then the curtain was raised upon the next act (8). The crime calls for justice, and the hunt for the perpetrator begins in Act III: "The capture was made and the fall of night formed the sable curtain which closed out the third act of the tragedy" (James 12). With a metaphor that echoes $16^{\text {th }}$-century revenge tragedy, the text makes the setting of the lynching an agent in the theatrical production as the earth's rotation provides lighting effects and the night's "sable curtain" falls on the third act. ${ }^{20}$ The final act stages the terrible retribution visited on the murderer: "a scaffold ten feet high was firmly erected, with every appliance necessary for the final act in the tragedy.... It rose up like a grim specter and bore the verdict of a united people upon its ominous front in the one word "Justice!" (James 14) Like the ghost in Hamlet, the "grim specter" of the scaffold cries out for revenge. Then the "play" culminates in the immolation of Henry Smith, a final act in which the whole community participates: "Slowly, impressively the 
cortege completed the circuit of the public square, passing down Church street toward the scene of the last act (James 18-19). In case Henry Smith's ordeal in this "passionplay of Texas" recalls for us Christ's suffering, the narrator presents it as the inversion of the crucifixion. Smith is cast as the "arch-villain" and his torments anticipate the fires of hell. In structuring events in this theatrical manner the writer lends dignity to a lynching that some of the contemporary commentators that he quotes in his book condemned for exceeding the boundaries of a purportedly civilized society.

Representing lynching as theatre prepared the spectators to anticipate a certain outcome. They would expect events to follow the generic conventions sketched out in the related discourse. Nevertheless, the meaning of the lynching spectacle was contested. The defenders of lynching argued that punitive violence was the only way to protect white womanhood and that "brutish black rapists" merited their horrific punishments. The critics charged that the lynchers' behavior demonstrated the dehumanizing effects of their racist culture.

In circulating beyond the communities in which a lynching took place, the images that denoted black abjection could be made to take on new signification. The anti-lynching lobby used them to reverse the intended message. Just as abolitionists located runaway advertisements published in Southern newspapers and reproduced them in their own antislavery publications, ${ }^{21}$ organizations like the NAACP repurposed lynching photographs to turn their stigmatizing force back against the white perpetrators. ${ }^{22}$ In one group photograph redirected to the nation in a NAACP circular published in 1935, men, women and children surround the lynch victim, whose lifeless body fills the center of the frame (Appendix Figure 9) ${ }^{23}$ The text beneath the photograph commands viewers to avoid looking at the central figure: "Do not look at the Negro. His earthly problems are ended." We are asked to concentrate instead on the figures in the background. There we see a cluster of people "neatly dressed" in summer clothes, as if for a Sunday outing, smiling for the camera. The text directs attention away from the victim in order to point out the callous way in which the white race dehumanizes its members in denying the humanity of its sacrificial victims.

The same tactic of repurposing lynching images can be found in a poster that appeared on the Senate chamber wall during the debate on an anti-lynching bill in $1937 .{ }^{24}$ Two photographs of burned bodies attached to trees accompany a text that denounces the impunity that such horrific travesties of justice meet with (Appendix Figure 10). The gruesome details of this lynching in Duck Hill, Mississippi were read at the hearings in the House of Representatives. The bill passed in the House but was filibustered in the Senate, and like other anti-lynching bills it failed to become law.

\section{Writers' responses to lynching}

21 The redeployment of lynching images and the creation of texts that countered the ideology of white supremacy ultimately helped in the struggle to gain legal rights for black citizens. However, their diffusion also had the effect of spreading the terror that lynching aimed to promote. Once seen, the images are so deeply burned into the mind that any words that evoke them can inspire fear. In fact, in the autobiographical account of his youth, published in 1948, Richard Wright even claimed that words are more powerful than direct experience: 
I had never in my life been abused by whites, but I had already been conditioned to their existence as if I had been victim of a thousand lynchings. [...]

The things that influenced my conduct as a Negro did not have to happen to me directly; I needed but to hear of them to feel their full effects in the deepest layers of my consciousness. (Black Boy 72-73)

Scenes of lynching haunt Wright's fiction and poetry as well as many other works by African Americans. Though the anti-lynching propaganda helped change laws, it did nothing to change the assignment of roles in the ritual. Whatever moral interpretation one assigns to lynching, whites still play the part of the executioners while blacks are the victims.

A number of plays written in the first decades of the $20^{\text {th }}$ century attempt to address the problem of representation. ${ }^{25}$ The tactic that playwrights adopted was not to stage lynching but to have it recounted either as an event in the remembered past-as in Angelina Wells Grimké's Rachel (1916)-or, or, as an off-stage occurrence, in the manner of Greek tragedy-as in Georgia Douglass Johnson's A Sunday Morning in the South (ca. 1925). The plays focus on the grief of the victims' families, in particular on the figure of the sorrowing mother. In this way, those African American playwrights answer back to the supremacist assertion that lynching protects white womanhood. Not only do their plays show the speciousness of that argument, they also represent the repercussions of racial violence on black families. Nonetheless, the problem with these plays' tragic resolutions is that they fail to provide the catharsis necessary to tragedy. Bloodletting cannot bring a return to order because in a racist society violence is itself order rather than its disruption. exposing the contradictions of black life in poetic laments that do not resolve them, but permit an ironic distance from them. The blues might even have been invented as a way for the community to face the challenge of living with the ever-present threat of being lynched. Although blues lyrics tend to concentrate on personal troubles, Adam Gussow has argued that some of the songs also refer covertly to lynching. In one blues lyric, the singer contemplates suicide in a manner that resonates strangely with lynching: "Gonna build me a scaffold. I'm gonna hang myself/ Cain't get the man I love, don't want nobody else" (Gussow 382). Another song evokes a similarly suicidal impulse:

Goin' down to de railroad,

Lay ma head on de track

I'm goin' to de railroad,

Lay ma head on de track-

But if I see de train a-comin'

I'm gonna jerk it back! (Hughes, Essays 213; Gussow 2).

lines are taken is a bluesy reworking of a spiritual from slavery time that grafts the tragi-comic lines about a flirtation with suicide onto the older song. For Gussow, they refer obliquely to the way in which a lynching was sometimes covered up by placing the victim's body on the railroad tracks to be further mutilated by the passage of a train (Gussow 2-3).

The blues is a way of coping with the "painful details and episodes of a brutal experience" (Ellison 79). ${ }^{26}$ The most poignant reference to lynching in a blues lyric is Abe Meeropol's "Strange Fruit," ${ }^{27}$ made all the more memorable by Billie Holiday's haunting interpretation. The song turns the spectacle of horror back onto the Southern 
community, subverting its idyllic self-portrait as the "gallant south" into a nightmarish scene. Monstrous hybrids haunt the land in the form of "strange fruit" with "bulging eyes and [...] twisted mouth." The "scent of magnolias" mingles with that of "burning flesh." The rottenness of the corpses infects the whole land, tainting the white community in the process. This song, as well as poems that embrace the blues aesthetic, like Jean Toomer's "A Portrait in Georgia" from Cane (1923) or Langston Hughes's "Song for a Dark Girl" (1927), borrow images from the lynching ritual to show the hypocrisy at the heart of the white Southern community. These evocations do not change the attribution of roles, but they expose the falsity of claims that it upholds law and decency.

Since lynching has been essential to the construction of racial difference, it has become entwined with ideas of African American identity. Richard Wright's poem, "Between the World and Me," gives a forceful account of the workings of this cultural mythology. It stages a recurrent literary topos-the discovery of the remains of a scene of lynching. It takes the blues form-"an autobiographical chronicle of personal catastrophe expressed lyrically" (Ellison 79)-and shows how the personal becomes general. Empathy with the lynched victim replicates the original insult, shaping African American subjectivity.

Walking in the woods, Wright's persona "stumbled/ suddenly upon the thing..." The word "thing" has a double significance as both an affair, the business that took place in the woods, and an inanimate object, the dehumanized remains of a man. The poem lists all the elements that allow the speaker to reconstitute the lynching scene. The ashes and bones in the "grassy clearing" belong to a body that was once clothed in the garments that now lie "vacant," "empty," "ripped" and "lonely." The last item of clothing in the list, "a pair of trousers," announces the victim's race and gender, for they are "stiff with black blood," an obvious reference to castration. In emasculating the victim, the lynchers alleviate the cultural anxieties centering on black masculinity, although the specter of the sexual power attributed to black men lingers on in the adjective "stiff." The dismembering and burning of the human body leaves the woods with a "charred stump," "a blunt/ finger," "torn limbs," and burnt "veins." And while the human victim can no longer protest, a burned sapling points "accusingly," a pathetic fallacy intimating that nature cries out against "the thing" that has occurred.

In counterpoint to all these empty or broken things, the poem lists the objects left behind by the lynch mob: "buttons, dead matches,/ butt-ends of cigars and cigarettes, peanut shells, a/ drained gin-flask, and a whore's lipstick." In juxtaposing the remnants of a scene of torture and those of a festive community gathering, the poem evokes, in negative as it were, those lynching photographs that seem designed to celebrate the collectivity through a group portrait with a corpse. One can easily reconstitute the lynching scenario from the traces that the speaker describes, because it has been reenacted so frequently in American communities and reproduced so voluminously in texts and images. Indeed, the first word of the poem is "And," a word that starts 12 of the poem's 54 lines and thereby suggests through anaphora the nightmarish recurrence of the scene that follows.

The speaker's discovery of the corpse is like a return of the repressed; the bones are "slumbering /forgottenly" until "the sooty details of the scene rose" like a ghost returning with a message for the living. In the course of the poem, the scene evoked metonymically in the opening stanza through the scattered objects takes on flesh. But 
in this replay the speaker himself is the victim who swallows his own blood, whose skin is coated with hot tar, and who is finally doused in gasoline. In a parody of resurrection he is immolated: "And in a blaze of red I leaped to the sky as pain rose like water, boiling my limbs." In the end the speaker's own body mirrors the remains he discovers. His own flesh becomes the abject "thing" that he found in the woods. Wright's protest poem dramatizes the violence of lynching by reproducing it in the pattern of empathic repetition evoked by Hinton Als. The scene reconstituted by Wright's speaker from its traces becomes the ritual he experiences in the flesh. The boundaries between inside and outside, self and other, do not hold. What begins as a lament for an unknown victim becomes the speaker's own death song. While he assumes the pre-scripted role of victim, his executioners join with him in a recurring ritual that reduces existential possibilities to the nightmarish replaying of the same spectacle of violence.

The recursiveness of social configurations of race can be seen in the way in which the title of Wright's poem echoes the opening line of W.E.B. Du Bois's justly celebrated work, The Souls of Black Folk. That book begins, "Between me and the other world, there is ever an unasked question..." (Du Bois 1). Wright signifies on this famous line by resignifying it: "the sooty details of the scene rose, thrusting/ themselves between the world and me...." In the poem, racial difference is felt much more strongly than $\mathrm{Du}$ Bois's veil, an image that suggests the almost unacknowledged, almost intangible ways in which the African American population is barred from access to the privileges that Americans claim. In Wright's poem blackness is produced with matches, tar and gasoline. Division does not simply mean "two warring ideals in one dark body" (Du Bois 3); it means being literally torn to pieces. ${ }^{28}$ Taking up Du Bois's phrase decades later and using it for the title of his autobiographical meditation Between the World and Me, TaNehisi Coates describes racism as: "a visceral experience, ... it dislodges brains, blocks airways, rips muscle, extracts organs, breaks teeth" (10). Coates echoes Wright here, suggesting that the violence of lynching actually produces racial difference. ${ }^{29}$

In the works produced before the Civil Rights era, the indignation of protest doubles with bluesy lamentations for the way things are. The desire to change the status quo wars with the sorry reality of America's racial history. Even in the $21^{\text {st }}$ century, decades after the successes of Civil Rights protests, lynching still looms large as a possible final act in the drama of individual black lives. The bodies that the American cultural imagination perceives as black still inspire the fantasies and fears that make them vulnerable to attack. These fantasies and fears are the underside of the American Dream analyzed so perceptively by Ta-Nehisi Coates in Between the World and Me. Reprising Du Bois's words and the title of Wright's poem, Coates addresses his son on the burden of being born black in a land of white privilege. His letter to his son is a thoughtful, deliberative act of remembrance for past and present victims as well as an accusing portrait addressed to America, in the tradition of anti-slavery and antilynching literature. Coates explains how violence is necessary to maintain America's racial divide because: "there is no them without you, and without the right to break you they must necessarily fall from the mountain, lose their divinity, and tumble out of the Dream" (105). African Americans live in constant fear, fear that too often translates into violence against the people in their own communities and families. For Coates this explains why his father beat him "with more anxiety than anger" (15) and why "extravagant boys" had recourse to "a catalogue of behaviors and garments enlisted to inspire the belief that [they] were in firm possession of everything they desired" (14). They were all "girding themselves against the ghosts of the bad old days when the 
Mississippi mob gathered 'round their grandfathers so that the branches of the black body might be torched, then cut away" (14). Although blacks rarely witnessed those scenes first hand, the traces left in photographs, in oral accounts, and in texts are enough to raise those ghosts.

The problem faced by artists and writers is that to represent lynching in any fashion is to contribute to perpetuating the cycle of terror, but to choose not to represent it is to leave representation in the hands of the racists. How then can black writers confront the problem of racist violence without making the black reader "feel like a nigger" (Als in Allen et al. 40)? To begin to change the cultural attribution of roles, writers would need to invent new rituals and new myths. In John Wideman's ironic novel, The Lynchers, published in 1973, the characters try to reverse the ritual and stage the lynching of a white policeman, but at the end of the narrative, the only victims are African Americans. The novel stages the ineffectuality of violent alternatives to nonviolent activism. The conspirators' attempt to simply reverse the roles only justifies increased repression.

Toni Morrison finds a more effective way to circumvent the dualism of racist violence in her fiction. Instead of focusing on the dynamics of white supremacy and black victimhood like the earlier protest fiction or reinforcing the racial divide by having black executioners murder white victims, as in Wideman's reversal of the pattern, Morrison's novels largely place white characters off-stage, beyond the range of vision of the black community. Her 1975 novel, Sula, offers perhaps the best example of her oblique literary strategy for figuring supremacist brutality. The events narrated in the novel's first chapter take place in 1919, a year that records numerous acts of violence asserting white supremacy. Black soldiers returning from the European front were particular targets, since their uniforms and medals suggested that they might be tempted to claim equal status with their white counterparts. The narrative features Shadrack, a soldier who has come back "blasted and permanently astonished by the events of 1917" (7). After being discharged from hospital, he is picked up by police who mistake his disorientation for drunkenness. An internally focalized narration stages a coded drama of lynching in Shadrack's center of consciousness. Describing his struggle to untie the shoelaces that the nurse has tied in double knots, the narrator declares that "his very life depended on the release of the knots" (12). Without actually representing it, the narrative evokes the struggle of the hanged man against the rope that strangles him. My interpretation might seem far-fetched except that this scene is a prelude to Shadrack's inauguration of National Suicide Day, an event that has "to do with making a place for fear as a way of controlling it" (14). In the ritual that he enacts every year on January third, he walks through the black neighborhood "with a cowbell and a hangman's rope calling the people together. Telling them that this was their only chance to kill themselves or each other" (14). This ritual recalls the blues lyric about building a scaffold. It concerns the only violence that the black community can hope to control-that which they themselves inflict. In this way, Shadrack introduces order into the community without harming any of its members.

Another instance of ritual violence in Sula is Eva's immolation of her only son. Through this act Eva tries, paradoxically, to restore the manhood that her son has lost during his absence from the Medallion community. Plum returns from the war a heroin addict and Eva descends painfully on her crutches from her habitual place in her bedroom to deal with the problem. In drenching her son with gasoline and applying the torch, she 
imitates the white lynchers' actions, but her reasoning is the opposite. When Hannah asks her later why she killed Plum, she explains that he was "being helpless and thinking baby thoughts and dreaming baby dreams and messing up his pants again..." (70). She burns him not to humiliate him and reduce him to nothing, but to save him. The burning thus has a sacramental dimension: as Eva pours on the gasoline, Plum imagines "the great wing of an eagle pouring a wet lightness over him" (47). The description of the murder of Plum inverts the logic of lynching, staging violence as compassion, and destruction as salvation.

In Sula Morrison imagines new rituals that borrow from the dominant scenario but change it, allowing violence to empower the black victims. Eva Peace's missing leg has the status of a legend in the Medallion community. When her husband abandons the family and they are on the verge of starvation, Eva disappears for several years and returns to Medallion minus one leg. The circumstances of the amputation are mysterious, but one of the explanations-that she "stuck it under a train and made them pay off" (31) recalls the blues lyric about the lure of the railroad track. Rather than being seen as a handicap though, Eva's missing leg becomes a source of wealth and power.

Later, Sula's gesture of cutting off the tip of her finger parallels the story of the missing leg and makes its connection with lynching more explicit. Sula responds to the white boys who threaten her and Nel by "pull[ing] out Eva's paring knife" and cutting off the tip of her finger: "Her aim was determined but inaccurate. She slashed off only the tip of her finger. The four boys stared open-mouthed at the wound and the scrap of flesh, like a button mushroom, curling in the cherry blood that ran into the corners of the slate" (55). With this strange image of the flesh becoming vegetal, the text weaves a rich mesh of connected suggestions. Sula's gesture evokes the division of the victim's body that is part of the lynching scenario. Fingers, toes, charred bones, or pieces of clothing or hair were prized souvenirs of spectacle lynchings. ${ }^{30}$ At the same time, the "mushroom" flesh and "cherry blood" intimate rape. However, the food imagery also suggests that Sula's sacrificial violence has a sacramental quality. In mutilating herself she anticipates and forestalls the threat posed by the girls' white tormenters. In a powerfully suggestive new ceremony, Sula resemiotizes some of the elements of the supremacist ritual.

In the logic of Morrison's novels, rituals of black-on-black violence are, paradoxically, the sole means of protecting black bodies in a racially divided society. A similar pattern is found in Beloved, where the slave mother's only way of saving her daughter from slavery is to murder her: "If I hadn't killed her she would have died and that is something I could not bear to happen to her" (200). The circular structure of Sethe's declaration confirms that, like the acts of violence in Sula, her action mimics the exactions of the whites. The essential difference is that mutilating one's own body or that of a loved one is a way of reclaiming one's identity by extracting it from the mythic structure that upholds white supremacy. ${ }^{31}$

These innovative Morrisonian rituals evoke lynching to challenge the whites' scopic privilege. They resemble the challenge issued by some of the anti-lynching texts evoked earlier, in turning the gaze onto the whites, but they manage to invest this reversal with a terrible force. In Beloved in particular, the mutilated black body takes on a power that resembles the terrifying head of the Medusa on Athena's shield. In fact, Sethe becomes a figure of the Medusa for the white slavecatchers, as she stands before 
them, her "eyes with no whites [...] gazing straight ahead" (151). The white men who come to claim Sethe's family have to avert their eyes from the spectacle. This passage is written in free indirect discourse and seen from the white men's point of view and its emphasis is on the impossibility of looking:

They didn't look at the woman in the pepper plants with the flower in her hat. They didn't look at the seven or so faces that had edged closer in spite of the catcher's rifle warning. Enough nigger eyes for now. Little nigger-boy eyes open in sawdust; little nigger-girl eyes staring between the wet fingers that held her face so her head wouldn't fall off; little nigger baby-eyes crinkling up to cry in the arms of the old nigger whose own eyes were nothing but slivers looking down at his feet. (150)

Through anaphora, the text marks the reversal of the usual specular configuration. The whites cannot bear to look because the "nigger eyes" have become obsessively present for them. Most important, Sethe's gaze cancels them out, making them disappear: "But the worst ones were those of the nigger woman who looked like she didn't have any. Since the whites in them had disappeared and since they were as black as her skin, she looked blind" (150). To meet the Gorgon's gaze, according to Jean-Pierre Vernant, is to be exposed to "the powers of the otherworld in their uttermost alterity, that of death, night, and nothingness" (301). ${ }^{32}$ Instead of meeting the slavecatchers in fear, Sethe confronts them heroically with an image of their own violence, reinforced by the power of love. Like the Gorgon, Sethe displays "a monstrousness based on a systematic scrambling of all the categories that the organized world distinguishes and that, in that face, mingle and interfere" (301-302). ${ }^{33}$ Sethe's ambivalence, like Sula's, makes her a pariah in her community, for these women refuse the asymmetrical configuration of power in the racial duality invented by the whites. They become heroic figures because of their aberrance from those social norms.

41 In conclusion, the ritualized lynchings of the early $20^{\text {th }}$ century staged spectacles that aimed to enforce the color line rather than to uphold justice. Their enactment bonded members of the white community and assigned them the privileged roles of executioners and spectators, while the only roles available for blacks were those of victims. The white participants branded black bodies as abject, marking them with the stigmata of criminality and then photographing them and diffusing their images like modern versions of the Italian pittura infamante. Because of their persistence as icons that proclaim the vulnerability of black bodies, images of lynching continue to instill fear into members of the black community. Through its representations, spectacle lynching continues to serve as a theater of power that coexists with America's federal institutions and renders them impotent. African American writers have to respond to that theatre of power that so forcefully assigns roles. Among the aesthetic strategies I have examined, Toni Morrison gives the most original and the most empowering reply to spectacle lynching. Rather than simply trying to counter one ritual of violence with another in a Nietzschean stand-off, she reassigns roles, so that the African American community take the parts of victims, executioners, and spectators. The spectacle is no longer aimed at indoctrinating, but at distancing. It forces readers, both black and white, to reflect on the meaning of violence rather than to take their places and their cues in a pre-scripted display of supremacy and abjection. 


\section{BIBLIOGRAPHY}

Allen, James, Hinton Als, John Lewis, and Leon Litwack. Without Sanctuary: Lynching Photography in America. Santa Fe: Twin Palms, 2000.

Apel, Dora. Imagery of Lynching: Black Men, White Women, and the Mob. New Brunswick, NJ: Rutgers UP, 2004.

Barthes, Roland. Camera Lucida: Reflections on Photography. Trans. Richard Howard. New York: Hill and Wang, 1981.

---. Image, Music, Text. Trans. Stephen Heath. New York: Hill and Wang, 1977.

Bayley, Harold. The Shakespeare Symphony, an Introduction to the Ethics of the Elizabethan Drama. London: Chapman and Hall, 1906.

Bredekamp, Horst. Théorie de l'acte d'image. Trans. Frédéric Joly and Yves Sintomer. Paris: La Découverte, 2015.

Brundage, William Fitzhugh. Lynching in the New South: Georgia and Virginia, 1880-1930. Chicago: U of Illinois P, 1993.

Coates, Ta-Nehisi. Between the World and Me. New York: Spiegel \& Grau, 2015.

Dray, Philip. At the Hands of Persons Unknown: The Lynching of Black America. New York: Random House, 2002.

Du Bois, W. E. Burghardt. The Souls of Black Folk: Essays and Sketches. Chicago: A. C. McClurg, 1903.

Ellison, Ralph. “Richard Wright's Blues." Shadow and Act. New York: Random House, 1964. 77-94.

Equal Justice Initiative, Lynching in America: Confronting the Legacy of Racial Terror. Montgomery, Alabama: Equal Justice Initiative, 2015.

https://eji.org/sites/default/files/lynching-in-america-second-edition-summary.pdf

Foucault, Michel. Discipline and Punish: The Birth of the Prison. Trans. Alan Sheridan. New York: Vintage, 1991.

Frisken, Amanda K. “'A Song Without Words: Anti-Lynching Imagery in the African American Press, 1889-1898." The Journal of African American History, 97 (Summer 2012): 240-269.

Girard, René, Violence and the Sacred. Baltimore: Johns Hopkins U.P., 1977.

Gussow, Adam. Seems like Murder Here: Southern Violence and the Blues Tradition. Chicago: U of Chicago, 2002.

Hale, Grace Elizabeth. Making Whiteness: The Culture of Segregation in the South, 1890-1940. New York: Vintage, 1998.

James, P. L. The Facts in the Case of the Horrible Murder of Little Myrtle Vance and Its Fearful Expiation at Paris, Texas, February 1st, 1893, with Photographic Illustrations. Paris, Texas: P. L. James, 1893.

Kato, Daniel. Liberalizing Lynching: Building a New Racialized State. New York: Oxford UP, 2015.

Lindsey, Rachel McBride. “'THIS BARBAROUS PRACTICE': Southern Churchwomen and Race in the Association of Southern Women for the Prevention of Lynching, 1930-1942," Journal of Southern Religion 16 (2014).

http://jsreligion.org/issues/vol16/lindsey.html. 
Loughran, Trish. The Republic in Print: Print Culture in the Age of U.S. Nation Building, 1770-1870. New York: Columbia UP, 2009.

Markovitz, Jonathan. Legacies of Lynching: Racial Violence and Memory. Minneapolis: U of Minnesota, 2004.

Morrison, Toni. Beloved. New York: Knopf, 1987.

---. Sula. New York: Knopf, 1973.

Nevels, Cynthia Skove. Lynching to Belong: Claiming Whiteness Through Racial Violence. College Station: Texas A. \& M. UP, 2007.

Perkins, Kathy A., and Judith L. Stephens, eds. Strange Fruit: Plays on Lynching by American Women. Bloomington: Indiana UP, 1998.

Peterson, Christopher. Kindred Specters: Death, Mourning, and American Affinity. Minneapolis: U of Minnesota, 2007.

Pfeifer, Michael James. Rough Justice: Lynching and American Society, 1874-1947. Chicago: University of Illinois Press, 2004.

Raiford, Leigh. "Photography and the Practices of Critical Black Memory." History and Theory 48 (2009): 112-29.

Rushdy, Ashraf H. A. The End of American Lynching. New Brunswick, NJ: Rutgers UP, 2012.

Smith, Gerald L., Karen Cotton McDaniel, and John A. Hardin, eds. The Kentucky African American Encyclopedia. Lexington, KY: U of Kentucky, 2015.

Tolnay, Stewart Emory and E.M. Beck. A Festival of Violence: An Analysis of Southern Lynchings, 1882-1930. Chicago: University of Illinois P., 1995.

Vernant, Jean-Pierre, and Pierre Vidal-Naquet. Mythe et Tragédie en Grèce Ancienne. Paris: La Découverte, 1986.

Waldrep, Christopher. The Many Faces of Judge Lynch: Extralegal Violence and Punishment in America. New York: Palgrave Macmillan, 2002.

Wideman, John Edgar. The Lynchers. New York: Harcourt Brace Jovanovich, 1973.

Wiegman, Robyn. American Anatomies: Theorizing Race and Gender. Durham: Duke UP, 1995.

Wood, Amy Louise. Lynching and Spectacle: Witnessing Racial Violence in America, 1890-1940. Chapel Hill: U of North Carolina, 2011.

Wright, Richard. "Between the World and Me." Partisan Review (July 1935), 18-19.

Wright, Richard. Works / Black Boy, the Outsider, Later Works. Ed. Arnold Rampersad. New York: Library of America, 1991.

Young, Harvey. “The Black Body as Souvenir in American Lynching." Theatre Journal 57.4 (2005): 639-57.

\section{APPENDIXES}

Appendix 


\section{FIgURE 1}

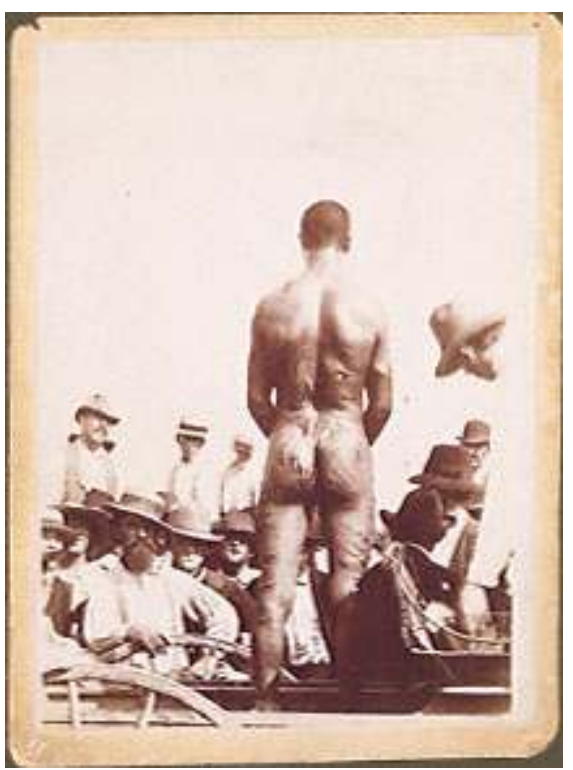

The lynching of Frank Embree (July 22, 1899, Fayette Missouri)

\section{FIgURE 2}

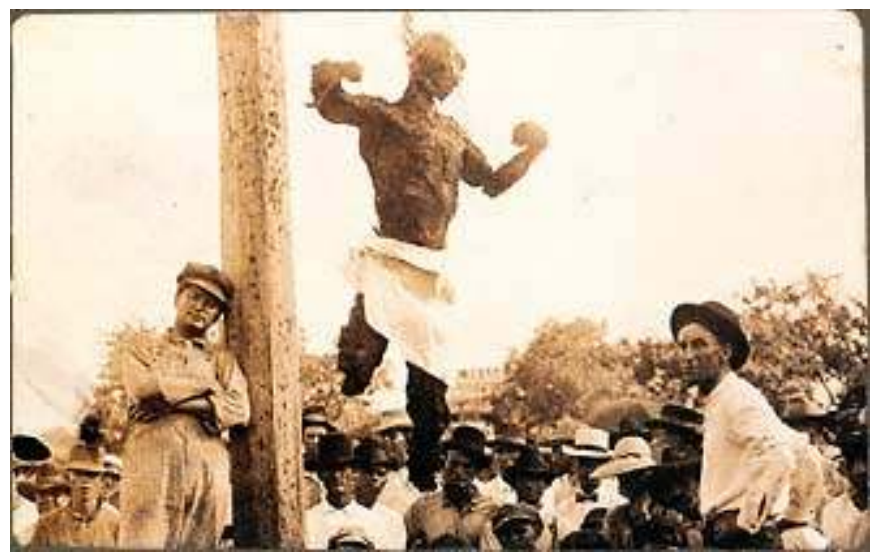

The lynching of Jesse Washington (May 16, 1916. Robinson, Texas)

FIgURE 3

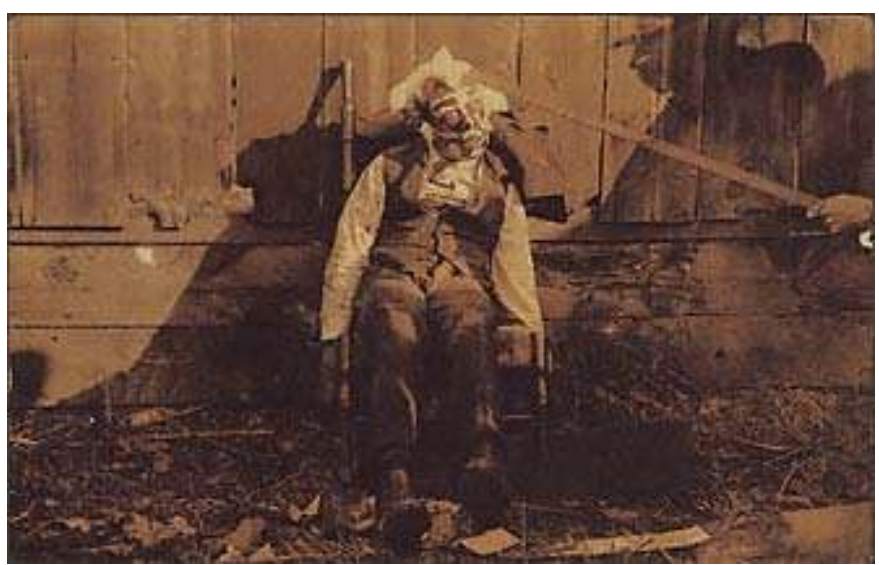

Circa 1900, location unknown. (Allen et al. 165). 


\section{FIgURE 4}

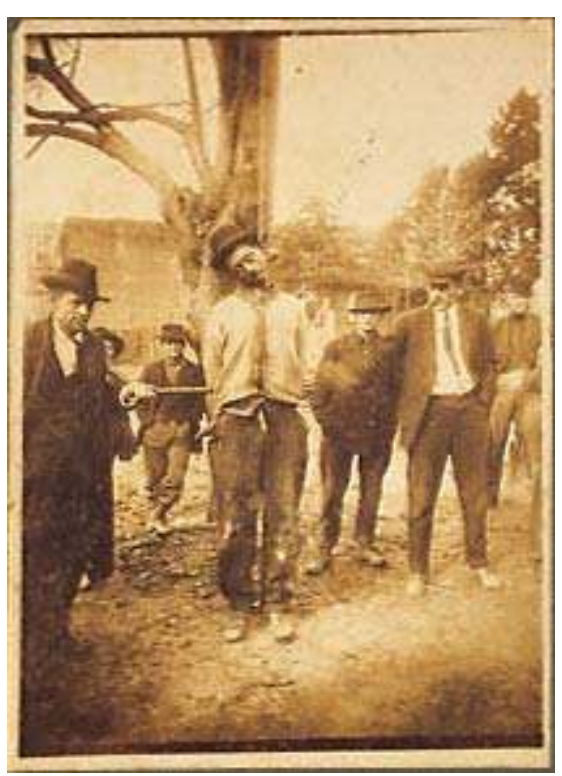

FIgURE 5

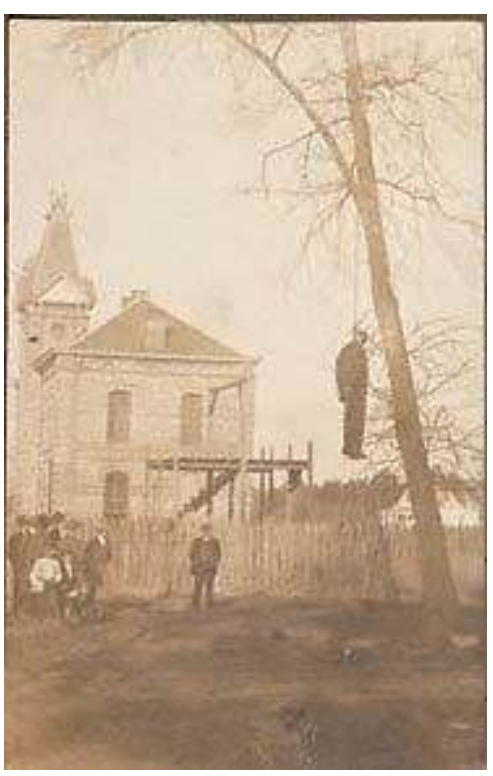

Unidentified corpse of African American male. Gallows, courthouse-jail, and windmill in background. 


\section{FIgURE 6}

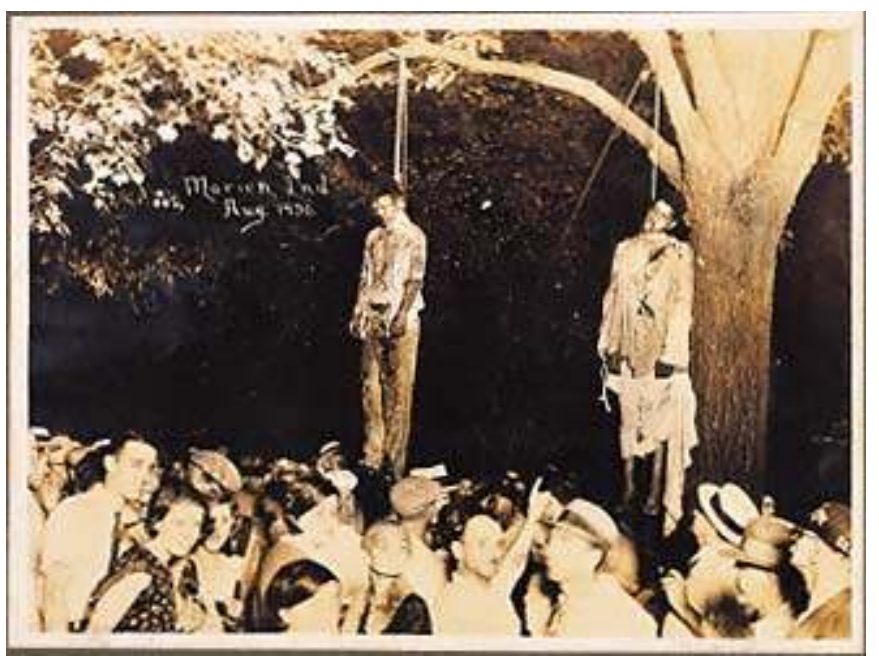

FIgURE 7

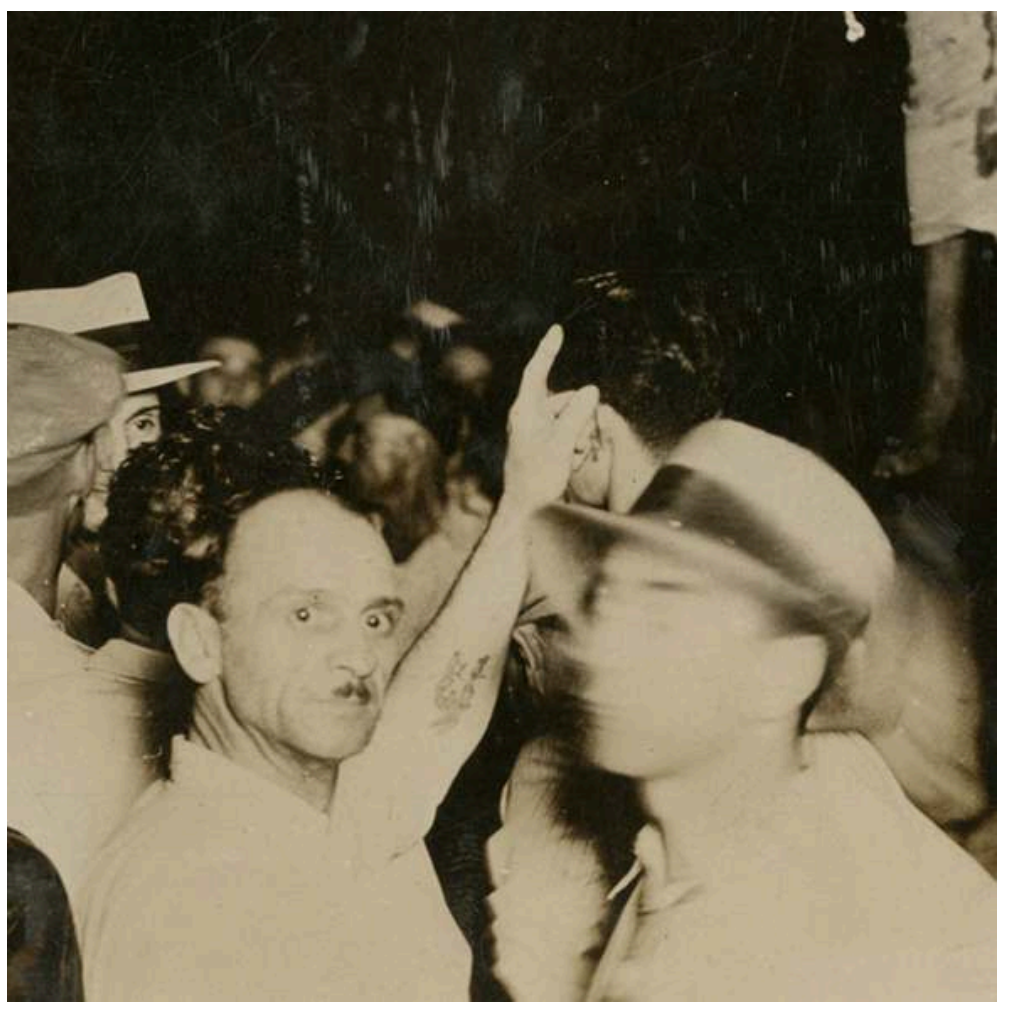




\section{FIgURE 8}

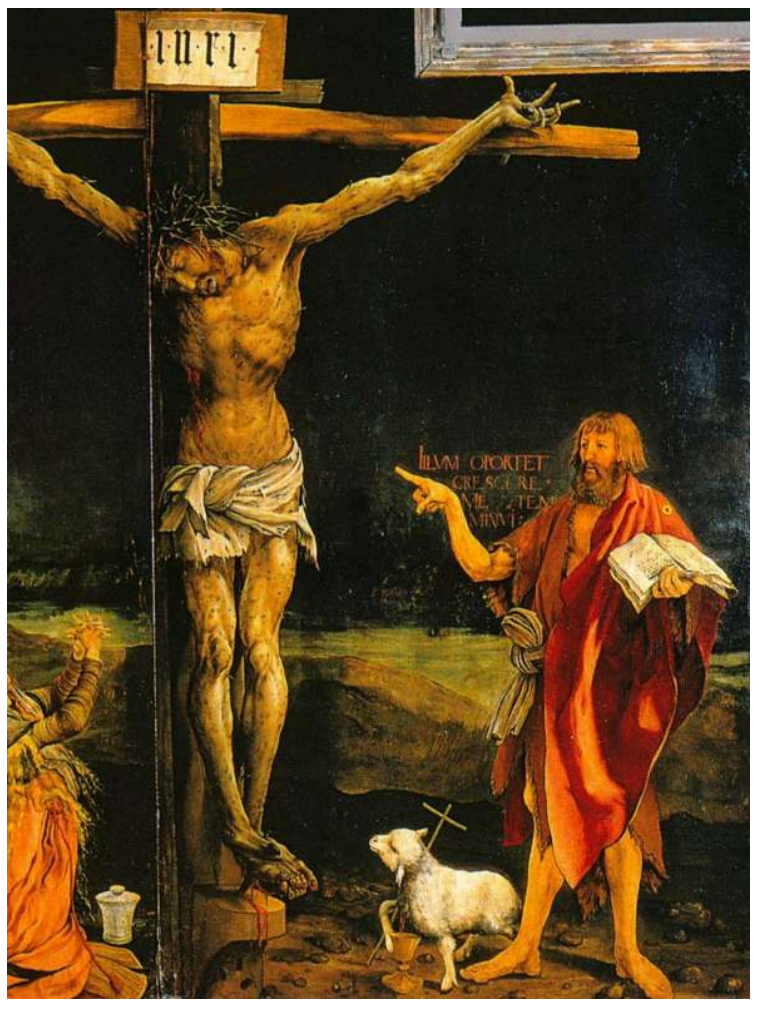

Detail from the Grunewald Crucifixion

FIgURE 9

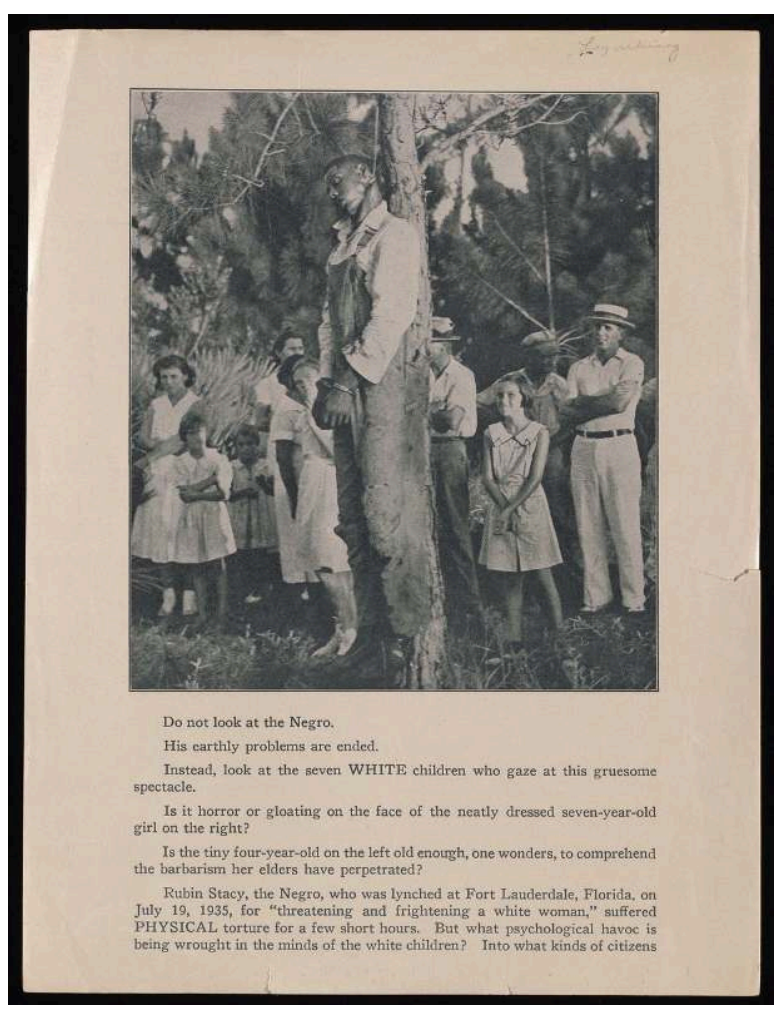

NAACP Anti-Lynching poster (1935)

FIgURE 10 


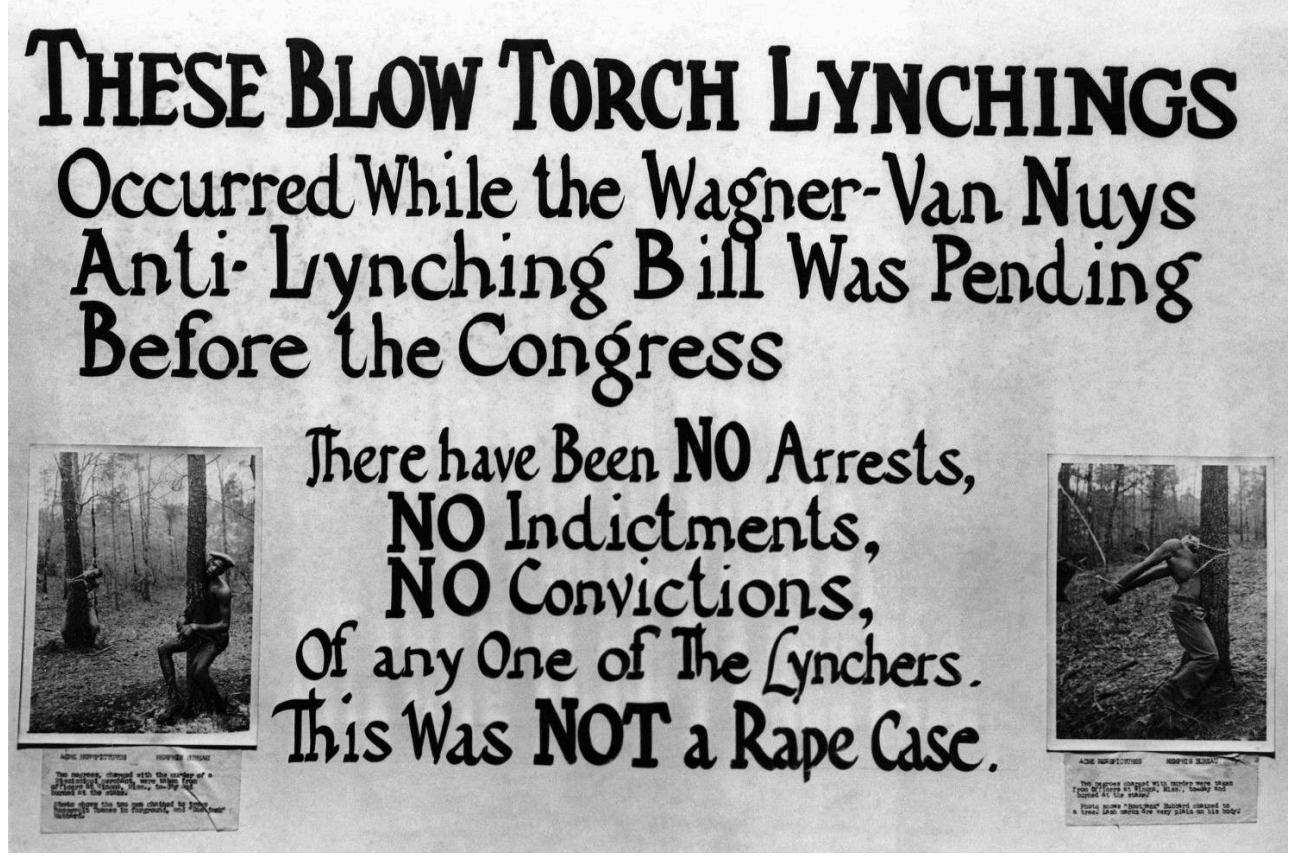

\section{NOTES}

1. I would like to thank the anonymous peer reviewers for their comments. Their suggestions, particularly concerning historical perspectives on the subject, were very helpful.

2. Some accounts give his name as Porter.

3. Grace Hale argues that with the development of consumer culture, the market for spectacles of black otherness grew, "and spectacle lynchings became a southern way of enabling the spread of consumption as a white privilege" (205).

4. Hale asserts that "spectacle lynchings became more powerful even as they occurred less frequently because the rapidly multiplying stories of these public tortures became virtually interchangeable" (206). After a period of relative silence on the part of historians, a large number of studies of the phenomenon have been published over the past decades, partly in response to the museum exhibition of James Allen's collection of lynching photographs and its publication in 2000 in the book, Without Sanctuary: Lynching Photography in America. A conference at Emory University in 2002 in conjunction with the exhibition brought together more than 90 historians to discuss the theme "Lynching and Racial Violence in America : Histories and Legacies."

5. The popular conception of lynching locates it in the American South and imagines its victims as exclusively African American. This is not strictly true, as documented victims also come from other racial and ethnic groups, and lynching took place in other areas of the country. Pfeifer's chronological and geographical survey of lynching in Chapter One of Liberalizing Lynching: Building a New Racialized State finds that the practice was "rare in the mid Atlantic and New England yet comparatively prevalent in the Midwest and West and abundant in the South" (36). W. Fitsburg Brundage explains that "Lynching, like slavery and segregation, was not unique to the South, but it assumed proportions and a significance that were without parallel elsewhere" (Brundage 3).

6. In The End of American Lynching Ashraf Rushdy discusses how theatre and lynching are similar (58-59). 
7. Statistics and dates for these lynchings cannot be established unequivocally. A 2015 report by the Equal Justice Initiative asserts that between 1877 and 1950, 3,959 black people were killed in "racial terror lynchings" in a dozen Southern states.

8. Cf. Hale's argument in Making Whiteness. Lynching historian Christopher Waldrep argues that "Lynching implied a killing carried out by a coherent community, an expression of localized popular sovereignty of the sort Southern white conservatives advocated" (68).

9. Steward Tolnay and Elwood M. Beck carried out an extensive study, published in their book $A$ Festival of Violence, that correlates fluctuations in the price of cotton to incidents of lynching. In the cotton states, increases in lynching corresponded to decreases in the price of cotton. They show too that the number of lynchings dropped when the demand for black labor rose, notably with the northward migration of the 1920s.

10. In Violence and the Sacred, Girard argues that societies create cohesion through the ritual exclusion of a chosen scapegoat. The violent sacrifice of the chosen victim resolves the conflicts among group members.

11. Cynthia Skove Nevels validates this hypothesis in her study of five lynchings in which immigrants of different European nationalities, whose membership in the dominant community was not secure, played crucial roles in launching the ritual.

12. Cf. Allen et al., Figure 43. I thank James Allen for allowing me to reproduce photographs from his collection. Given the distressing effect these photographs have on viewers, I have chosen to include them in an Appendix at the end of this article rather than in the body of the text.

13. Allen identifies the postcard as "The lynching of Jesse Washington. May 16, 1916. Robinson, Texas" (Allen et al., Figure 26).

14. The notes on the plates in Without Sanctuary describe the postcard in the following way: "The bludgeoned body of an African American male, propped in a rocking chair, blood-spattered clothes, white and dark paint applied to face, circular disks glued to cheeks, cotton glued to face and head, shadow of man using rod to prop up the victim's head. Circa 1900, location unknown. Gelatin silver print. Real Photo postcard. 5 3/8 x 2 7/8" (Allen et al. 165).

15. Without Sanctuary describes the photograph (Plate 2) in the following manner : "Unidentified corpse of African American male. Gallows, courthouse-jail, and windmill in background. Nine onlookers, two young boys.1900-1915. Location unknown. Gelatin silver print. Real photo postcard. 3 x 5 in. The architectural details of the courthouse in the background suggest a Texas origin. Found in Texas" (Allen et al. 166).

16. My translation. "Une sorte de rétrocouplage exista probablement de tout temps entre les actes de violence tels que les lynchages et leur diffusion photographique, dans la mesure où les photographies étaient considérées comme un élément même de l'exécution et le fait de les regarder comme une participation à cette exécution » (Bredekamp 212).

17. See Barthes's moving account of his search for a photograph that "accords with [his] mother's being and [his] grief at her death" (Barthes 1981, 63-71).

18. This is the meaning that Richard Wright gives it in his short story "Going to Meet the Man." 19. Hale argues that this lynching was distinctive in that it was "the first blatantly public, actively promoted lynching of a southern black by a large crowd of southern whites. Adding three key features-the specially chartered excursion train, the publicly sold photograph, and the widely circulated, unabashed retelling of the event by one of the lynchers-the killing of Smith modernized and made more powerful the loosely organized, more spontaneous practice of lynching that had previously prevailed" (207).

20. Harold Bayley lists some quotations from Tourneur, Beaumont and Fletcher and Marston, among others, in which the night is figured as a black or sable curtain (308-309).

21. See Trish Loughran's The Republic in Print for a discussion of the work Theodore Weld and his wife, Angelina Grimké, and her sister, Sarah Grimké, accomplished in sorting through thousands 
of Southern newspapers to gather the documentation on slavery for Weld's 1839 American Slavery as It Is : Testimony of a Thousand Witnesses (Loughran 354-359).

22. See the discussions by Dora Apel and Amy Wood. Amanda K. Frisken demonstrates that from the 1890s African American newspapers published drawings depicting lynchings to protest against racial violence and to counter the illustrations in the supremacist press (for example, the National Police Gazette) depicting black men as rapists.

23. Rachel McBride Lindsey identifies the victim as Rubin Stacy. Lindsey contextualizes the photograph as an effort to sway public opinion in favor of anti-lynching legislation : "by framing racially-motivated vigilantism as crime threatening white communities as well as black, as a scourge on democracy instead of specific murderous acts."

24. Senator Bennett Clark (D-Mo.) admitted being responsible for the poster's appearance (Wood 198).

25. A number of these plays are gathered in the collection edited by Kathy A Perkins and Judith Stephens.

26. "The blues is an impulse to keep the painful details and episodes of a brutal experience alive in one's aching consciousness, to finger its jagged grain, and to transcend it, not by the consolation of philosophy, but by squeezing from it a near-tragic, near-comic lyricism" (Ellison 79).

27. The poem first appeared under the pseudonym Lewis Allen in the New York Teacher (1937) and later in the New Masses. Billie Holiday recorded it in 1939.

28. Later on in The Souls of Black Folk, Du Bois suggests the terror that sustains America's racially divided society when he speaks of the birth of his son : "Holding in that little head-ah, bitterly! -he unbowed pride of a hunted race, clinging with that tiny dimpled hand-ah, wearily !-to a hope not hopeless but unhopeful, and seeing with those bright wondering eyes that peer into my soul a land whose freedom is to us a mockery and whose liberty a lie. I saw the shadow of the Veil as it passed over my baby, I saw the cold city towering above the blood-red land" (209). The "blood-red land" conflates Georgia's red clay and the spilled blood of black Americans, while "the cold city" suggests the indifference of the dominant community.

29. Leigh Raiford argues that for African Americans, lynching and lynching photographs have constituted a sort of "primal narrative" of the black experience of citizenship (117).

30. Harvey Young studies this practice at length in his essay, "The Black Body as Souvenir in American Lynching," discussing how lynching keepsakes serve as souvenirs, fetishes and remains. In Dusk at Dawn W.E.B. Du Bois recounts how he joined the fight against lynching in earnest when, after Sam Hose had been lynched in front of two thousand spectators, he saw "that his knuckles were on exhibition at a grocery store" in Atlanta, for sale as souvenirs. See the discussion in Phillip Dray's opening chapter.

31. As Christopher Peterson points out, for Sethe "To kill her own daughter is to claim that daughter as her own over and above the master's claim. [...] But if to kill is to claim as one's own, then the reverse is also true : the claim of possession is always violent" (78).

32. My translation. «Exposé au regard de Gorgô, l'homme s'affronte aux puissances de l'au-delà dans leur altérité la plus radicale, celle de la mort, de la nuit, du néant » (Vernant 301).

33. My translation. «Une monstruosité basée sur un brouillage systématique de toutes les catégories que le monde organisé distingue et qui, en ce visage, se mêlent et interfèrent » (Vernant 301-302). 


\section{ABSTRACTS}

The spectacle lynchings of the early $20^{\text {th }}$ century performed a ritual that assigned roles and distributed racial identities in American society. Representation was an essential component of the ritual, ensuring its diffusion in the images and narratives produced in response to the events. Beginning with a discussion of the lynching photography gathered in James Allen's Without Sanctuary: Lynching Photography in America, this essay goes on to consider the difficulties that African American writers confront in responding to the images that cast their people in the role of victims. Richard Wright's poem "Between the World and Me" illustrates how representations of the lynching ritual induce a recurrent cycle of terror that haunts his black speaker. Ta-Nehisi Coates's 2015 book demonstrates how the political, literary and existential problem endures. Recognizing how representation ensures the replication of racial divisions, Toni Morrison evokes the lynching spectacle in ways that scramble its categories and suggest new configurations of power.

Les spectacles de lynchages du début du $20^{\text {ème }}$ siècle accomplissaient un rituel qui assignait des rôles et définissait les identifications raciales au sein de la société américaine. La représentation était une composante essentielle du rituel facilitant sa diffusion à travers les images et les récits produits à la suite des événements. Partant d'une discussion des photographies de lynchage contenues dans l'ouvrage de James Allen, Without Sanctuary: Lynching Photography in America, cette étude analyse les difficultés auxquelles les écrivains afro-américains doivent faire face pour traiter les images qui placent leur peuple en position de victimes. Le poème de Richard Wright, "Between the World and Me," illustre la façon dont les représentations du rituel de lynchage déclenchent un cycle récurrent de terreur qui hante l'énonciateur noir. Le livre de Ta-Nehisi Coates publié en 2015 montre la persistance de ces problématiques aussi bien existentielles que politiques et littéraires. Tout en reconnaissant le rôle des représentations dans la reproduction des clivages raciaux, Toni Morrison évoque le lynchage spectacle dans des termes qui redéfinissent ses catégories et suggèrent de nouveaux rapports de forces.

\section{INDEX}

Keywords: African American, blues, identity, lynching, photography, representation, race, Beloved, Sula, Between the World and Me, "Between the World and Me"

Mots-clés: afro-américain, blues, littérature, lynchage, photographie, représentation, race, Beloved, Sula, Between the World and Me, "Between the World and Me"

\section{AUTHORS}

\section{WENDY HARDING}

Professor

Université de Toulouse Jean Jaurès

harding@univ-tlse2.fr 